Archive for

Organic Chemistry

Arkivoc 2017, part v, 187-195

\title{
A facile synthesis of racemic aggregation pheromones of palm pests, Rhinoceros beetle and Rhynchophorus weevil
}

\author{
Chi-Hien Dang, ${ }^{b, c}$ Van-Dung Le, ${ }^{b}$ Cong-Hao Nguyen, ${ }^{b, c}$ and Thanh-Danh Nguyen, ${ }^{* a, c}$
}

a Institute of Research and Development, Duy Tan University, Da Nang City, Vietnam

${ }^{b}$ Graduate University of Science and Technology, Vietnam Academy of Science and Technology,

18 Hoang Quoc Viet, Cau Giay, Hanoi, Vietnam

'Institute of Chemical Technology, Vietnam Academy of Science and Technology, 1 Mac Dinh Chi Street,

District 1, Ho Chi Minh City, Vietnam

Email: danh5463bd@yahoo.com

Received 07-20-2017

Accepted 09-27-2017

Published on line 10-16-2017

\section{Abstract}

Pheromones of palm pests were successfully synthesized using a Grignard coupling as the key step. The synthesis of ethyl 4-methyloctanoate (1), the Oryctes rhinoceros L. aggregation pheromone, was achieved from 2bromohexane via two pathways with overall yields over 40\%. 4-Methyl-5-nonanol (2), and 4-methyl-5nonanone (3), Rhynchophorus ferrugineus Oliv. aggregation pheromones, were synthesized by nucleophilic addition of a Grignard reagent to an aldehyde to afford a diastereoisomeric mixture of alcohols with varying ratios of threo and erythro isomera, and then oxidized with Jones reagent in overall yields of over $75 \%$.

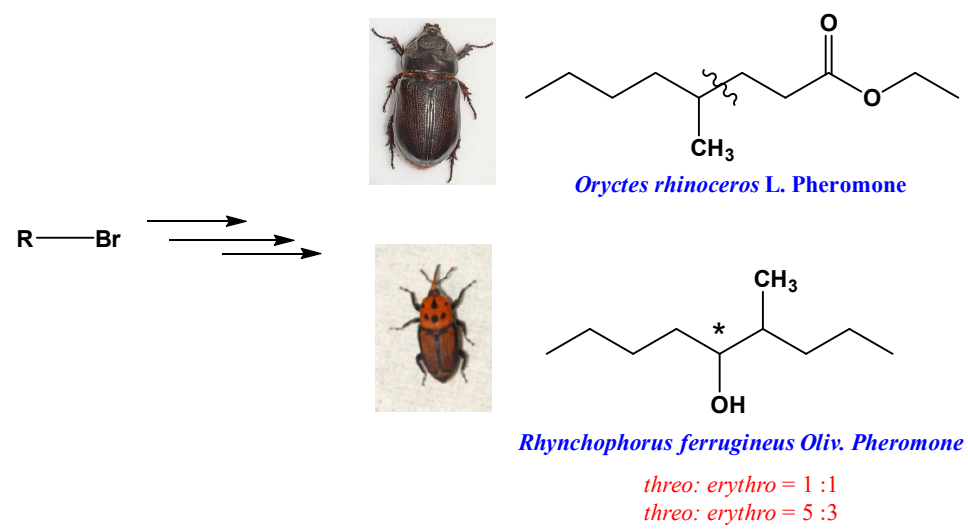

Keywords: Pheromone, Oryctes rhinoceros, Rhynchophorus ferrugineus, Grignard coupling 
Rhinoceros beetle (Oryctes rhinoceros L.) and rhynchophorus weevil (Rhynchophorus ferrugineus Oliv.) are two of the most importantly destructive pests of coconut trees (Cocos nucifera) and other palms in tropical Southern Asia, Pacific and Indian islands. ${ }^{1-3}$ Their aggregation pheromones include the methyl-branched ethyl ester (1), secondary alcohol (2) and ketone (3) (Figure 1).

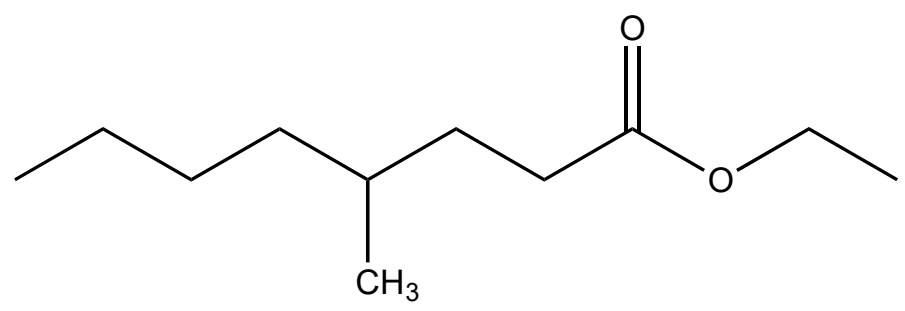

ethyl 4-methyloctanoate (1)

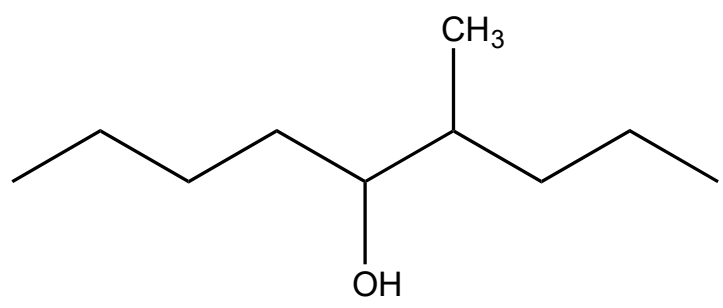

4-methyl-5-nonanol (2)

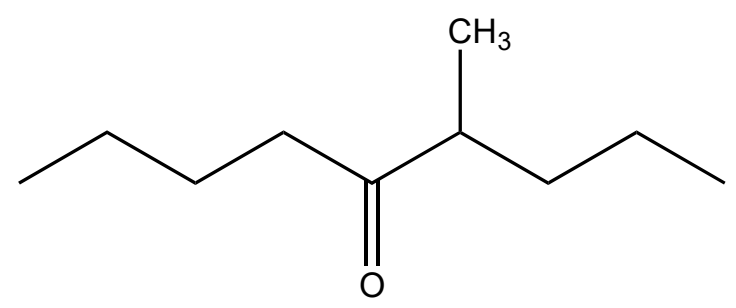

4-methyl-5-nonanone (3)

Figure 1. Structure of aggregation pheromones of Oryctes rhinoceros L. (1) and Rhynchophorus ferrugineus Oliv. (2 and 3)

The aggregation pheromone of $O$. rhinoceros was identified by Hallett et al. ${ }^{4}$ as ethyl 4 -methyloctanoate. Field trials showed that the attraction of racemic 1 to be substantially more effective than attraction of both (4S)-1 and (4R)-1 enantiomers. It was also found that a combination of $\mathbf{2}$ and $\mathbf{3}$ was an aggregation pheromone of $R$. ferrugineus. The effectiveness of both the $(4 S, 5 S)$ isomer of $\mathbf{2}$ and racemic $\mathbf{2}$ was shown by evaluation in traps, indicating them to be the most powerful attractants in operational programs to control the red weevil in palm plantations. ${ }^{5-8}$ Therefore, effective and cost-efficient control of the insect populations is possible with pheromones and enhanced synthetic routes to these pheromones became an important goal. Thus the $(R)$ - and $(S)$-isomers of 1 were prepared from the respective optical isomers of citronellol. ${ }^{4}$ The racemic mixture was obtained by conjugate addition of an organocuprate to ethyl acrylate ${ }^{9}$ or coupling between an alkyl iodide and ethyl acrylate in the presence of a Ni catalyst ${ }^{10}$ or Grignard reagent coupling with ethyl 4-bromobutanoate. ${ }^{11}$ Recently, Ragoussis et al. ${ }^{12}$ have described an efficient route from hexanal to synthesize $R$. ferrugineus pheromone $\mathbf{2}$ in four steps (greater than 50\% overall yield) while many different approaches for its synthesis 
have recently been reported. The most commonly useful way for the preparation of chiral compound $\mathbf{2}$ was from a chiral species such as an epoxy alcohol, ${ }^{13}$ a methyl-branched alcohol, ${ }^{7}$ a methyl-branched epoxide ${ }^{14}$ or an organolithium. ${ }^{15}$ Recently, isomer $(4 S, 5 S)$ - 2 was synthesized by asymmetric aldol condensation between the boron enolate derived from $(4 R, 5 S)$-4-methyl-5-phenyl-3-propionyl-2-oxazolidinone and pentanal, followed by Grignard coupling with the corresponding alkyl. ${ }^{16}$ However, the methods reported above involve starting materials that are not readily available and/or use of complicated routes that are unsuitable for large scale preparations. A low-cost synthesis is essential for the practical use of these pheromones. Our previous studies had shown that the racemic mixture of pheromones could be obtained in an economical pathway from commercially available starting materials. ${ }^{17-19}$ Taking into account the drawbacks, it was decided to design an effective path to the racemic aggregation pheromones of Rhinoceros beetle and Rhynchophorus weevil to control the population of the insects. Herein, we describe an efficient procedure for the synthesis of pheromones from simply commercial starting materials.

\section{Results and Discussion}

\section{Synthesis of $\mathrm{O}$. rhinoceros pheromone}

In our initial synthetic work to the 0 . rhinoceros pheromone, ${ }^{20} 2,6$-dimethyl-2-decene was prepared from natural citronellol then converted by a one-step oxidation using $\mathrm{KMnO}_{4}-\mathrm{FeCl}_{3}$ into 4-methyloctanoic acid, which was then esterified with microwave-assistance, giving 1 in an overall yield of over $60 \%$ (Figure 2). However, this reaction generated a small content of minor products that complicated the purification process.
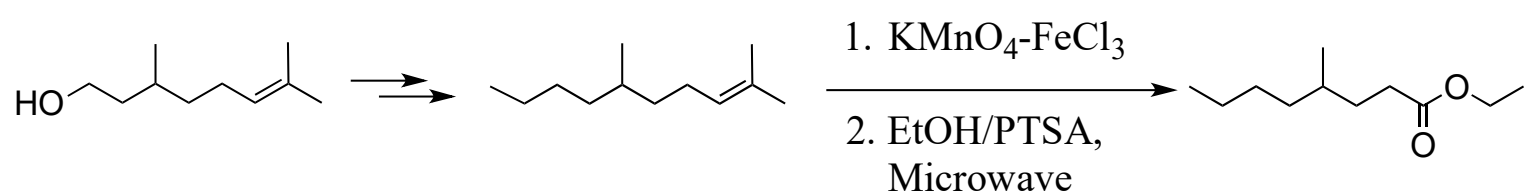

Figure 2. Synthesis of ethyl 4-methyloctanoate (1) from natural citronello ${ }^{20}$

In the present work, the synthetic strategy to make 1 used the retrosynthetic analysis shown in Figure 3 . The important key intermediate, 4-methyloctanoic acid, would be obtained by oxidation of the respective aldehyde or alcohol, which would be synthesized from two fragments, 2-bromohexane (fragment A) and a bromoaldehyde or bromo-alcohol unit (fragment B). Efficient syntheses of the fragment B have been reported from acrolein ${ }^{17}$ and diols. ${ }^{18}$

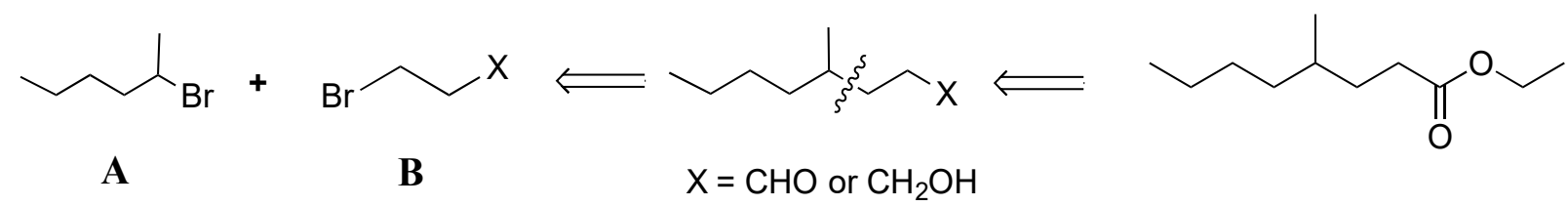

Figure 3. Synthetic strategy to the $O$. rhinoceros pheromone

The synthetic route in the present work is shown in Figure 4. Reaction of the Grignard reagent prepared from 4, with 3-bromopropanal ethyleneglycol acetal or 2-((3-bromopropyl)oxy)tetrahydro-2H-pyran was 
performed as a crucial step. Our first route led to the aldehyde $6 \mathrm{a}$ and involved a Grignard coupling at $0{ }^{\circ} \mathrm{C}$ in the presence of dilithium tetrachlorocuprate $\left(\mathrm{Li}_{2} \mathrm{CuCl}_{4}\right)$ followed by protective group cleavage with $50 \%$ aqueous acetic acid in a yield over $65 \%$ for two steps. In the second route, we prepared the alcohol $\mathbf{6 b}$, the intermediate $\mathbf{5 b}$ bearing tetrahydropyran group was mildly deprotected using PTSA in metanol, with a yield of $78 \%$ for the two steps. Oxidation of $\mathbf{6 a}$ or $\mathbf{6} \mathbf{b}$ with $\mathrm{KMnO}_{4}$ afforded the acid $\mathbf{7}$ in $76 \%$ and $73 \%$ yields, respectively. Finally, the acid 7 was mildly esterified with ethanol and PTSA to afford the pheromone 1 in 81\% yield by microwave heating in five minutes. The latter pathway, which not only led to the products in higher overall yields, but also in which economical and nontoxic starting materials were used, is preferred for the preparation of the pheromone.

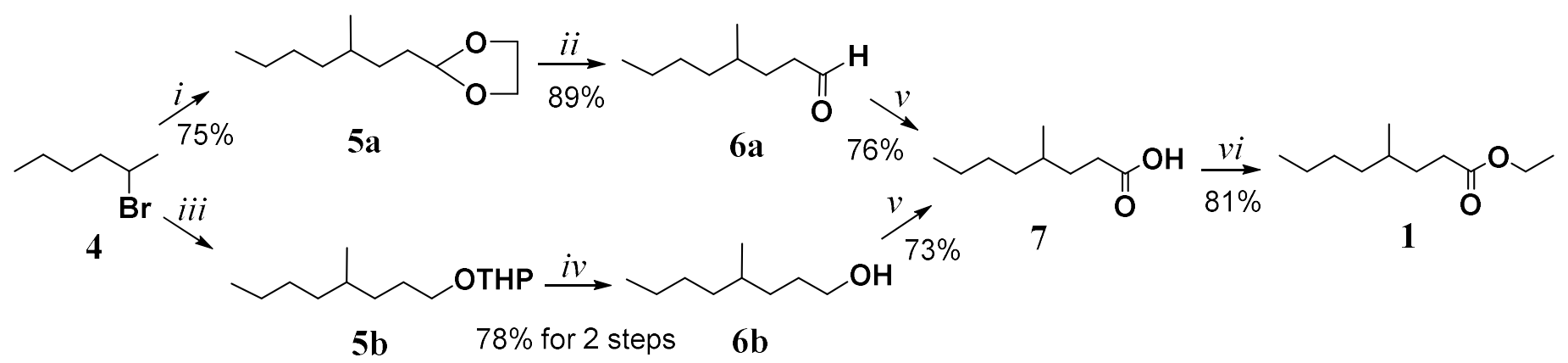

Figure 4. Synthesis of pheromone 1. Reaction conditions: i) 1. Mg, THF 2. 3-bromopropanal ethyleneglycol acetal, $\mathrm{Li}_{2} \mathrm{CuCl}_{4},-78{ }^{\circ} \mathrm{C}$; ii) $50 \%$ aq. $\mathrm{CH}_{3} \mathrm{COOH}$; iii) 1. $\mathrm{Mg}$, THF 2. 2-((3-bromopropyl)oxy)tetrahydro-2H-pyran, $\mathrm{Li}_{2} \mathrm{CuCl}_{4},-78{ }^{\circ} \mathrm{C}$; iv) PTSA, MeOH, $50^{\circ} \mathrm{C}$; v) $\mathrm{KMnO}_{4}, \mathrm{Na}_{2} \mathrm{CO}_{3}, 0^{\circ} \mathrm{C}$; vi) EtOH, PTSA, microwave.

\section{Synthesis of R. ferrugineus pheromones}

For the synthesis of $R$. ferrugineus pheromone $\mathbf{2}$, approach A utilized pentanal (8a) as the aldehyde component in reaction with the Grignard reagent generated from 2-bromopentane (9a). Because the nucleophilic Grignard reagent addition to an aldehyde commonly results in a racemic mixture of secondary alcohols, the present reaction generated a mixture of two diastereoisomers (threo: erythro) $2 \mathbf{a}$ in a 1:1 ratio as revealed by analysis of the ${ }^{1} \mathrm{H}$ NMR spectrum (Figure $6 \mathrm{~A}$ ).<smiles>CCCC(C)CC(C)(C)C(C)(C)C</smiles>

$8 \mathbf{a}$ Approach B<smiles>CCCC(C)C=O</smiles>

$8 \mathbf{b}$<smiles>CCCCC(O)C(C)CCC</smiles>

$\mathbf{2 a}$ or $\mathbf{2 b}$<smiles>CCCCC(O)C(CCC)OC#N</smiles>

2a<smiles>CCCCC(O)C(CCC)C(C)O</smiles>

$2 \mathbf{b}$

Figure 5. Synthesis of pheromones 2 and 3. Reaction conditions: i) $\mathrm{Mg}, \mathrm{THF}, 0{ }^{\circ} \mathrm{C}$ ii) Jones reagent 
A

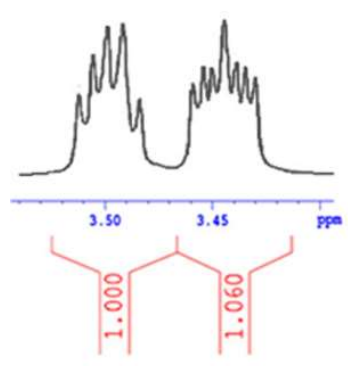

B

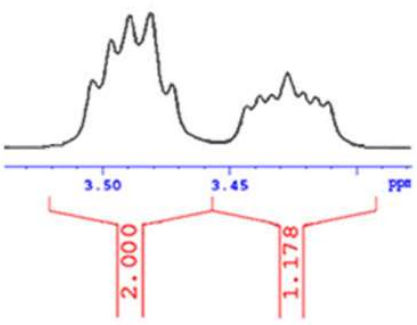

Figure 6. ${ }^{1} \mathrm{H}$ NMR spectra (500 MHz) analysis of $\mathbf{2 a}(\mathbf{A})$ and $\mathbf{2 b}(\mathbf{B})$

In approach B, 2-methylpentanal (8b) as the aldehyde component was reacted with the Grignard reagent generated from 1-bromobutane (9b) to afford the pheromone $\mathbf{2 b}$ in $\mathbf{9 4 \%}$ yield (Figure 5). According to Cram's rule, the Grignard reagent has the choice of approach from the two faces of the carbonyl group and is much more likely to opt for the less hindered face. As illustrated in Figure 7, the threo isomer should be a major product. The peak corresponding to the proton at $\mathrm{C}-5$ for the threo isomer is a multiplet at $\delta 3.50\left(\mathrm{CDCl}_{3}\right)$ while the one corresponding to the erythro isomer appears at $\delta 3.44\left(\mathrm{CDCl}_{3}\right)^{7,15}$ The ratio of the two diastereoisomeric isomers (threo:erythro) clearly observed from the NMR spectrum (Figure 6B) is 5:3. Finally, the alcohol 2 was treated with the Jones reagent to afford racemic ketone $\mathbf{3}$ in $85 \%$ yield.<smiles>Cc1ccc(C=O)c(C)c1</smiles>

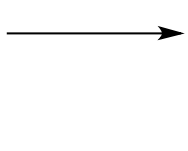

Figure 7. Application of Cram's rule for the synthesis of $\mathbf{2} \mathbf{b}$

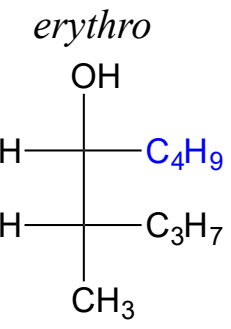

minor<smiles>CCCCCCC(O)C(C)CCCCC</smiles>

major

\section{Conclusions}

This work demonstrates a short, simple and efficient synthetic route to a racemic mixture of aggregation pheromones. Compound 1, O. rhinoceros pheromone, was synthesized via two routes in overall yields of $40 \%$ (via aldehyde) and 46\% (via alcohol). The R. ferrugineus pheromone $\mathbf{2}$ was synthesized by two different approaches which generated a diastereoisomeric mixture with different ratios of threo and erythro isomers. Pheromone $\mathbf{3}$ was produced by oxidation with the Jones reagent in overall yields of over $75 \%$. These ratios contribute to multiform options in the practical use of pheromones as environmentally benign tools for pest control. 


\section{Experimental Section}

General. All manipulations were performed under a dry nitrogen atmosphere using Schlenk techniques. All of the materials were purchased from Merck (Germany) or Aldrich. THF was dried with $\mathrm{Na} /$ benzophenone and freshly distilled prior to use. The other solvents were purchased from Fluka and used without further purification. Column chromatography was performed with Merck Kieselgel 60. Esterification was carried out under microwave-assistance in a SANYO EM-D9553N reactor. IR spectra were recorded on a Bruker Equinox 55 IR spectrophotometer. ${ }^{1} \mathrm{H}(500 \mathrm{MHz})$ and ${ }^{13} \mathrm{C}(125 \mathrm{MHz})$ NMR spectra were determined on a Bruker AVANCE 500 NMR spectrometer using $\mathrm{CDCl}_{3}$ as solvent and tetramethylsilane (TMS) as an internal standard. Chemical shifts are reported in $\delta$ relative to TMS. GC-MS analyses were carried out using an Agilent Technologies 6890N (USA). Refractive indices $\left(n_{D}\right)$ were measured with an Abbe refractometer Way-2S.

( \pm )-4-Methyloctanal ethylenglycol acetal (5a). The Grignard reagent solution obtained from 4 (16.5 g, $0.1 \mathrm{~mol})$ and magnesium $(2.4 \mathrm{~g}, 0.1 \mathrm{~mol})$ in anhydrous THF $(30 \mathrm{~mL})$ was slowly added dropwise using a syringe to a solution of 3-bromopropanal ethyleneglycol acetal $(8.24 \mathrm{~g}$; $0.05 \mathrm{~mol})$ in THF $(20 \mathrm{~mL})$ containing a catalytic amount of $\mathrm{Li}_{2} \mathrm{CuCl}_{4}\left(4 \mathrm{~mL}, 0.2 \mathrm{M}\right.$ solution in THF) at $0{ }^{\circ} \mathrm{C}$. After stirring overnight at ambient temperature, the mixture was poured into an aqueous solution of $\mathrm{NH}_{4} \mathrm{Cl}$ and extracted with $\mathrm{Et}_{2} \mathrm{O}$. The organic layer was washed with a saturated aqueous solution of $\mathrm{NaHCO}_{3}$, water and brine, then dried (anhydrous $\mathrm{MgSO}_{4}$ ) and concentrated under reduced pressure to afford $\mathbf{5} \mathbf{a}$ as a colorless liquid $(14.0 \mathrm{~g}, 75 \%$ yield) after purification by chromatography using $\mathrm{Et}_{2} \mathrm{O} /$ hexane $(1: 10)$ as the eluent, $n_{\mathrm{D}}{ }^{29}=1.4280$; IR: 2955, 2867, 1732, 1461, 1406, 1132, 1041, 878, 807 $\mathrm{cm}^{-1} ;{ }^{1} \mathrm{H}$ NMR $\left(500 \mathrm{MHz}, \mathrm{CDCl}_{3}\right) \delta 0.89(\mathrm{~m}, 6 \mathrm{H}), 1.1-1.47(\mathrm{~m}, 8 \mathrm{H}), 1.58-1.71(\mathrm{~m}, 3 \mathrm{H}), 3.81-3.98(\mathrm{~m}, 4 \mathrm{H}), 4.83(\mathrm{t}$, $J 5.0 \mathrm{~Hz}, 1 \mathrm{H}) .{ }^{13} \mathrm{C} \mathrm{NMR}\left(125 \mathrm{MHz}, \mathrm{CDCl}_{3}\right) \delta 14.1,19.6,23.0,29.2,31.1,31.5,32.7,36.6,64.8,105.0$.

( \pm )-4-Methyloctanal (6a). A solution of $5 \mathrm{a}(5.05 \mathrm{~g}, 27 \mathrm{mmol}$ ) and aq AcOH (25 mL, 50\%) was stirred at ambient temperature for $2 \mathrm{~h}$ (monitored by GC). The reaction mixture was poured into saturated brine and the product was extracted with $\mathrm{Et}_{2} \mathrm{O}$. The combined organic layers were washed with $\mathrm{NaHCO}_{3}$ solution, brine and dried $\left(\mathrm{MgSO}_{4}\right)$. The solvent was evaporated to afford $6 \mathrm{a}$ a colorless liquid $(3.41 \mathrm{~g}, 89 \%$ yield) after purification by distillation under reduced pressure (b.p. $\left.85^{\circ} \mathrm{C} / 25 \mathrm{mmHg} ; n_{\mathrm{D}}{ }^{29}=1.4228\right)$. GC-MS; $m / z$ : $43,56(100), 70,85,95$, 109, 124; IR, $v_{\max } / \mathrm{cm}^{-1} 2925,2864,1729$ (C=O), 1459, 1378, 1260, 1027, 805; ${ }^{1} \mathrm{H} \mathrm{NMR}\left(500 \mathrm{MHz}, \mathrm{CDCl}_{3}\right) \delta 0.81$ $(\mathrm{m}, 6 \mathrm{H}), 1.21(\mathrm{~m}, 8 \mathrm{H}), 1.51-1.61(\mathrm{~m}, 1 \mathrm{H}), 2.34(\mathrm{~m}, 2 \mathrm{H}), 9.70(\mathrm{t}, \mathrm{J} 1.8 \mathrm{~Hz}, 1 \mathrm{H}) ;{ }^{13} \mathrm{C} \mathrm{NMR}\left(125 \mathrm{MHz}, \mathrm{CDCl}_{3}\right) \delta 14.1$, $19.4,22.9,28.9,29.2,32.4,36.4,41.7,203.0$.

( \pm )-4-Methyloctan-1-ol (6b). The Grignard reagent solution obtained from 4 (16.5 g, $0.1 \mathrm{~mol}$ ) and magnesium $(2.0 \mathrm{~g}, 0.1 \mathrm{~mol})$ in anhydrous THF $(30 \mathrm{~mL})$ was slowly added dropwise using a syringe to a solution of 2-((3bromopropyl)oxy)tetrahydro-2H-pyran $(11.5 \mathrm{~g}, 0.05 \mathrm{~mol})$ in THF $(20 \mathrm{~mL})$ containing a catalytic amount of $\mathrm{Li}_{2} \mathrm{CuCl}_{4}\left(4 \mathrm{~mL}, 0.2 \mathrm{M}\right.$ solution in THF) at $0{ }^{\circ} \mathrm{C}$. After stirring overnight at ambient temperature, the mixture was poured into an aqueous solution of $\mathrm{NH}_{4} \mathrm{Cl}$ and extracted with $\mathrm{Et}_{2} \mathrm{O}$. The organic layer was washed with an aqueous solution of $\mathrm{NaHCO}_{3}$, water and brine, then dried with anhydrous $\mathrm{MgSO}_{4}$ and concentrated under reduced pressure to afford the crude product $(5 \mathbf{b})(12 \mathrm{~g})$. A mixture of the crude $\mathbf{5 b}, p$-toluenesulfonic acid (PTSA) $(300 \mathrm{mg})$ and $\mathrm{MeOH}(200 \mathrm{~mL})$ was stirred at $50{ }^{\circ} \mathrm{C}$ for $2 \mathrm{~h}$. The mixture was then concentrated to halfvolume, poured into aq $\mathrm{NaHCO}_{3}$ solution and the product was extracted with $\mathrm{Et}_{2} \mathrm{O}$. The combined organic layers were washed with brine, dried $\left(\mathrm{MgSO}_{4}\right)$ and the solvent was evaporated to afford $6 \mathbf{b}(11.2 \mathrm{~g}, 78 \%$ yield for two steps) as a colorless liquid after purification by distillation under reduced pressure (b.p. $89^{\circ} \mathrm{C} / 20 \mathrm{mmHg} ; n_{D}{ }^{29}=$ 1.4318); IR ( $\left.v_{\max }, \mathrm{cm}^{-1}\right) 3352(\mathrm{br}, \mathrm{OH}), 2926,2863,1459,1378,1124,1063,901,733 ;{ }^{1} \mathrm{H} \mathrm{NMR}\left(500 \mathrm{MHz}, \mathrm{CDCl}_{3}\right)$ 
$\delta 0.87(\mathrm{~m}, 6 \mathrm{H}), 1.15-1.40(\mathrm{~m}, 8 \mathrm{H}), 1.48(\mathrm{~m}, 2 \mathrm{H}), 1.50-1.71(\mathrm{~m}, 1 \mathrm{H}), 3.61(\mathrm{t}, J 6.8 \mathrm{~Hz}, 2 \mathrm{H}) ;{ }^{13} \mathrm{C} \mathrm{NMR}(125 \mathrm{MHz}$, $\left.\mathrm{CDCl}_{3}\right) \delta 14.1,19.6,23.0,29.2,30.3,32.6,32.9$.

( \pm )-4-Methyloctanoic Acid (7). A solution of $\mathrm{KMnO}_{4}(2.84 \mathrm{~g}, 20.0 \mathrm{mmol}), \mathrm{Na}_{2} \mathrm{CO}_{3}(0.5 \mathrm{~g} ; 4.72 \mathrm{mmol})$ 6a (2.2 g, $14.0 \mathrm{mmol})$ or $6 \mathrm{~b}(2.0 \mathrm{~g}, 14.0 \mathrm{mmol})$ in water $(100 \mathrm{~mL})$ was stirred at $0{ }^{\circ} \mathrm{C}$ for $3 \mathrm{~h}$. After stirring at rt for an additional $3 \mathrm{~h}$, the solid was filtered off and the filtrate was neutralized by addition of aq $\mathrm{HCl}$ solution (10\%). The water layer was extracted with $\mathrm{Et}_{2} \mathrm{O}$. The combined organic layers were washed with brine, dried $\left(\mathrm{MgSO}_{4}\right)$ and the solvent was evaporated. The pure product 7 as a colorless liquid was obtained by chromatography using $\mathrm{Et}_{2} \mathrm{O} /$ hexane (1:5) as the eluent and yields calculated for $\mathbf{6 a}$ and $\mathbf{6 b}$ were $76 \%$ and $73 \%$, respectively; $n_{D}{ }^{29}=$ 1.4302; GC-MS, m/z 43, 57 (100), 69, 73, 83, 99, 129; IR $\left(v_{\max }, \mathrm{cm}^{-1}\right)$ 3447, 2959, 2922, 2870, 1718 (C=0), 1461, $1378,1267,1184,1111,1075,981,743 ;{ }^{1} \mathrm{H}$ NMR $\left(500 \mathrm{MHz}, \mathrm{CDCl}_{3}\right): \delta 0.91(\mathrm{~m}, 6 \mathrm{H}), 1.12-1.31(\mathrm{~m}, 6 \mathrm{H}), 1.42-1.49$ $(\mathrm{m}, 2 \mathrm{H}), 1.66-1.69(\mathrm{~m}, 1 \mathrm{H}), 2.31-2.40(\mathrm{~m}, 2 \mathrm{H}), 11.2$ (br., $1 \mathrm{H}) ;{ }^{13} \mathrm{C} \mathrm{NMR}\left(125 \mathrm{MHz}, \mathrm{CDCl}_{3}\right) \delta$ 14.1, 19.3, 23.0, 29.1, 31.7, 31.9, 32.3, 36.3, 180.6 .

( \pm )-Ethyl 4-methyloctanoate (1). Anhydrous EtOH (6.9 g, $150.0 \mathrm{~mol})$ was added to a mixture of 7 (1.0 g; 7.0 $\mathrm{mmol})$, PTSA (0.05 g; $0.32 \mathrm{mmol})$ and anhydrous heptane $(10 \mathrm{~mL})$ in a $20 \mathrm{~mL}$ screw top microwave reaction vessel equipped with a stir bar. The vessel was then capped. The reaction was carried out in microwave conditions: $100{ }^{\circ} \mathrm{C}, 5 \mathrm{~min}$ and $200 \mathrm{~W}$. The reaction mixture was poured into distilled water and extracted with hexane. The combined organic layers were washed with brine, dried (anhydrous $\mathrm{MgSO}_{4}$ ) and the solvent was evaporated. The pure pheromone 1 was obtained as a colorless liquid by chromatography using $\mathrm{Et}_{2} \mathrm{O} / \mathrm{hexane}$ $(1: 10)$ as the eluent $\left(1.06 \mathrm{~g}, 81 \%\right.$ yield, b.p. $\left.86^{\circ} \mathrm{C} / 12 \mathrm{mmHg}\right) ; n_{\mathrm{D}}{ }^{29}=1.4256 . \mathrm{GC}-\mathrm{MS}, \mathrm{m} / \mathrm{z} 43,55,60,73,83,88$, 101 (100), 111, 124, 129, 141, 157; IR ( $\left.v_{\max } \mathrm{cm}^{-1}\right)$ 2926, 2865, 1738 (C=O), 1459, 1377, 1254, 1173, 1112, 1034, 933, 857, 781; ${ }^{1} \mathrm{H}$ NMR $\left(500 \mathrm{MHz}, \mathrm{CDCl}_{3}\right) \delta 0.88(\mathrm{dt}, J 3.0 \mathrm{~Hz}, J 7.0 \mathrm{~Hz}, 6 \mathrm{H}), 1.12-1.30(\mathrm{~m}, 6 \mathrm{H}), 1.25(\mathrm{t}, J 7.0 \mathrm{~Hz}, 3$ $\mathrm{H}), 1.44(\mathrm{~m}, 2 \mathrm{H}), 1.66(\mathrm{~m}, 1 \mathrm{H}), 2.30(\mathrm{~m}, 2 \mathrm{H}), 4.12(\mathrm{q}, J 7.0 \mathrm{~Hz}, 2 \mathrm{H}) ;{ }^{13} \mathrm{C} \mathrm{NMR}\left(125 \mathrm{MHz}, \mathrm{CDCl}_{3}\right): \delta 14.1,14.3$, $19.3,23.0,29.2,32.0,32.2,32.4,36.4,60.2,174.2$.

( \pm )-4-Methyl-5-nonanol (threo: erythro $=1: 1,2 a)$. A solution of pentanal $(8 \mathrm{a})(25.0 \mathrm{mmol})$ cooled to $0{ }^{\circ} \mathrm{C}$ in anhydrous THF ( $30 \mathrm{~mL}$ ) was slowly added dropwise using a syringe to the Grignard reagent prepared from 2bromopentane (9a) $(50.0 \mathrm{mmol})$ and magnesium ( $1.2 \mathrm{~g}, 50.0 \mathrm{mmol})$ in anhydrous THF $(30 \mathrm{~mL})$, then the mixture was stirred at ambient temperature for $6 \mathrm{~h}$. The mixture was poured into an aqueous solution of $\mathrm{NH}_{4} \mathrm{Cl}$ and extracted with $\mathrm{Et}_{2} \mathrm{O}$. The organic layer was washed with an aqueous solution of $\mathrm{NaHCO}_{3}$, water and brine, then dried with anhydrous $\mathrm{MgSO}_{4}$ and concentrated under reduced pressure to afford $2 \mathrm{a}$ (threo: erythro $=1: 1$ ) as a colorless liquid (89\% yield). $90^{\circ} \mathrm{C} / 13 \mathrm{mmHg} ; n_{\mathrm{D}}{ }^{29}=1.4298$; GC-MS, $m / z$ 29, 39, 41, 45, 55, 59, 67,69 (100), 83, 87, 101, 140; IR ( $\left.v_{\max }, \mathrm{cm}^{-1}\right) 3371(\mathrm{br}, \mathrm{OH}), 2956,2867,1460,1380,1116,1019,978,898,738 ;{ }^{1} \mathrm{H}$ NMR $(500$ $\left.\mathrm{MHz}, \mathrm{CDCl}_{3}\right) \delta$ 0.86-0.94 (m, $\left.18 \mathrm{H}\right), 1.09-1.48(\mathrm{~m}, ~ 22 \mathrm{H}), 3.43(\mathrm{~m}, \sim 1 \mathrm{H}), 3.50(\mathrm{~m}, 1 \mathrm{H}) ;{ }^{13} \mathrm{C} \mathrm{NMR}(125 \mathrm{MHz}$, $\left.\mathrm{CDCl}_{3}\right) \delta 13.5,14.1,14.3,14.4,15.2,20.4,20.5,22.8,22.8,28.3,28.5,33.1,34.2,34.2,35.6,37.9,38.6,75.2$, 76.1.

( \pm )-4-Methyl-5-nonanol (threo: erythro $=\mathbf{5 : 3 , 2 b}$ ). In a similar procedure to the synthesis of $\mathbf{2 a}$, pheromone $\mathbf{2 b}$ (threo:erythro $=5: 3$ ) was obtained as a colorless liquid from reaction between 2-methylpentanal (8b) and 1bromobutane $(9 \mathrm{~b})$ as the starting materials (94\% yield). $98^{\circ} \mathrm{C} / 13 \mathrm{mmHg} ; n_{\mathrm{D}}{ }^{29}=1.4296 ;{ }^{1} \mathrm{H} \mathrm{NMR}\left(500 \mathrm{MHz}, \mathrm{CDCl}_{3}\right)$ $\delta$ 0.85-0.92 (m, 14.4 H), 1.06-1.51 (m, 17.6 H), $3.44(\mathrm{~m}, \sim 0.6 \mathrm{H}), 3.50(\mathrm{~m}, 1 \mathrm{H}) ;{ }^{13} \mathrm{C} \mathrm{NMR}\left(125 \mathrm{MHz}, \mathrm{CDCl}_{3}\right) \delta$ 13.6, 14.4, 14.1, 14.4, 15.3, 20.5, 20.5, 22.8, 22.8, 28.4, 28.5, 33.10, 34.2, 34.2, 35.7, 37.9, 38.6, 75.2, 76.1.

( \pm )-4-Methyl-5-nonanone (3). The Jones chromic acid reagent $(8 \mathrm{~N}, 80 \mathrm{~mL})$ was added to a solution of $\mathbf{2 a}$ or $\mathbf{2 b}$ $(1.58 \mathrm{~g}, 0.01 \mathrm{~mol})$ in $\mathrm{Me}_{2} \mathrm{CO}(150 \mathrm{ml})$ with stirring and ice cooling. The mixture was stirred for $2 \mathrm{~h}$. The excess oxidant was destroyed by the addition of a small amount of propan-2-ol. The solvent was evaporated. The residue was mixed with water and extracted with $\mathrm{Et}_{2} \mathrm{O}$. The ether solution was washed with water, brine, dried over $\mathrm{MgSO}_{4}$ and evaporated. The residue was filtered through a silica gel column and distilled to give $\mathbf{3}$ as a colorless liquid ( $1.32 \mathrm{~g}, 85 \%$ yield); b.p. $85^{\circ} \mathrm{C} / 13 \mathrm{mmHg}$ (lit. ${ }^{7} 48-50$ ㅇ $\mathrm{C} / 2 \mathrm{mmHg}$ ); $n_{\mathrm{D}}^{29}=1.4215$. GC-MS; $m / z 29$, 
39, 41, 43, 55, 57 (100), 71, 85, 99, 114, 127; IR ( $\left.v_{\max }, \mathrm{cm}^{-1}\right)$ 2959, 2871, 1711 (C=0), 1459, 1373, 1248, 1118, 1042,$743 ;{ }^{1} \mathrm{H}$ NMR $\left(500 \mathrm{MHz}, \mathrm{CDCl}_{3}\right) \delta$ 0.88-0.93 (m, $\left.6 \mathrm{H}\right), 1.05-1.06(\mathrm{~d}, J 7.0 \mathrm{~Hz}, 3 \mathrm{H}), 1.23-1.34(\mathrm{~m}, 4 \mathrm{H}), 1.51-$ $1.63(\mathrm{~m}, 4 \mathrm{H}), 2.40-2.44(\mathrm{dt}, J 2.3 \mathrm{~Hz}, 5.0 \mathrm{~Hz}, 2 \mathrm{H}), 2.51-2.55$ (q, J $6.7 \mathrm{~Hz}, 1 \mathrm{H}) ;{ }^{13} \mathrm{C} \mathrm{NMR}\left(125 \mathrm{MHz}, \mathrm{CDCl}_{3}\right) \delta 13.9$, $14.1,16.4,20.5,22.5,25.9,35.2,40.9,46.1,215.2$.

\section{Acknowledgement}

The authors thank Prof. Dr. Chu Pham Ngoc Son (President of Chemical Society of Ho Chi Minh City) for NMR spectra discussion.

\section{Supplementary Material}

Characterization data and ${ }^{1} \mathrm{H}$ and ${ }^{13} \mathrm{C}$ NMR spectra for all of the synthesized compounds associated with this article can be found in the online version.

\section{References}

1. Jacoba, T. K.; Bhumannavar, B. S. Trop. Pest Manage. 1991, 37, 80-84. https://doi.org/10.1080/09670879109371542

2. Zelazny, B.; Alfiler, A. R. Environ. Entomol. 1986, 15, 84-87. https://doi.org/10.1093/ee/15.1.84

3. Dang, C. H.; Nguyen, C. H.; Im, C.; Nguyen, T. D. In Integrated Pest Management (IPM): Environmentally Sound Pest Management, Gill, H. Ed.; Intech: Rijeka, Croatia, 2016; p103-127.

4. Hallett, R. H.; Perez, A. L.; Gries, G.; Gries, R.; Pierce, Jr . H. D.; Yue, J.; Oehlschlager, A. C.; Gonzalez, L. M.; Borden, J. H. J. Chem. Ecol. 1995, 21, 1549-1570.

https://doi.org/10.1007/BF02035152

5. Hallett, R. H.; Gries, G.; Gries, R.; Borden, J. H.; Czyzewska, E.; Oehlscnlager, A. C.; Pierce, Jr. H. D.; Angerilli, N. P. D.; Rauf, A. Naturwissenschaften 1993, 80, 328-331.

https://doi.org/10.1007/BF01141908

6. Gunawardena, N. E.; Herath, H.M.W.K.B. J. Natn. Sci. Coun. Sri Lanka 1995, 23, 81-86.

7. Perez, A. L.; Hallett, R. H.; Gries, R.; Gries, G.; Oehlschlager, A. C.; Borden, J. H. J. Chem. Ecol. 1996, 22, 357368.

https://doi.org/10.1007/BF02055104

8. Hoddle, M. S.; Hoddle, C. D. Pakistan Entomologist 2011, 33, 77-80.

9. Gries, G.; Gries, R.; Perez, A. L.; Oehlschlager, A. C.; Gonzales, L. M.; Pierce, Jr. H. D.; Zebeyou, M.; Kouame, B. Z. Naturforsch. 1994, 49c, 363-366.

10. Sim, T. B.; Choi, J.; Yoon, N. M. Tetrahedron Lett. 1996, 37, 3137-3140. https://doi.org/10.1007/BF02055104

11. Vechorkin, O.; Hu, X. Angew. Chem. Int. Ed. 2009, 48, 2937-2940. https://doi.org/10.1002/anie.200806138 
12. Ragoussis, V. ; Giannikopoulos, A.; Skoka, E.; Grivas, P. J. Agric. Food Chem., 2007, 55, 5050-5052. https://doi.org/10.1021/if0704662

13. Mori, K.; Kiyota, H.; Malosse, C.; Rochat, D. Liebigs Ann. Chem. 1993, 1993, 1201-1204. https://doi.org/10.1002/jlac.1993199301194

14. Swatschek, J.; Grothues, L.; Bauer, J. O.; Strohmann, C.; Christmann, M. A. J. Org. Chem. 2014, 79, 976-983. https://doi.org/10.1021/j0402422b

15. Oehlschlager, A. C.; Prior, R. N. B.; Perez, A. L.; Gries, R.; Gries, G.; Pierce, Jr. H. D. J. Chem. Ecol. 1995, 21, 1619-1629. https://doi.org/10.1007/BF02035156

16. Odriozola, J. M.; García, J. M.; González, A.; Gil, P. Tetrahedron: Asymmetry 1999, 10, 4627-4632. https://doi.org/10.1016/S0957-4166(99)00528-5

17. Dang, C. H.; Nguyen, C. H.; Nguyen, C. T. H. G.; Le, T. S.; Nguyen, T. D. in $12^{\text {th }}$ Asian chemical congress 2007, Proceeding of Environment and Green Chemistry Symposium, Putra World Trade Centre, Kuala Lumpur, Malaysia, 23-25, Aug. 2007, Lee, Y. H.; Wong, L. S. Eds. Malaysian institute of chemistry, Malaysia, 2007, p. 115-123.

18. Nguyen, T. D.; Nguyen, C. H.; Im, C.; Dang, C. H. Chem. Pap. 2015, 69, 380-384.

19. Nguyen, T.D.; Nguyen, C.H.; Im, C.; Dang, C. H. Chem. Nat. Compd. 2016, 52, 877-879.

20. Nguyen, C. H.; Dang, C. H.; Nguyen, C. T. H. G. Vietnam J. Chem. 2003, 41, 125-130. 